\title{
Weed Interference Affects Dry Bean Yield and Growth
}

\author{
Hossein GHAMARI*, Goudarz AHMADVAND \\ Bu-Ali Sina University, Faculty of Agriculture, Department of Agronomy and Plant Breeding, Janbazan \\ Street, Hamedan, Iran; Ghamari130@gmail.com ( ${ }^{*}$ corresponding author)
}

\begin{abstract}
Dry bean is one of the most important pulse crops in Iran. Field study was conducted in 2011 to evaluate effects of weed competition from a natural flora on growth and yield of dry bean (Phaseolus vulgaris L.). The treatments consisted of weed infestation and weed removal periods $(10,20,30,40$ and 50 days) after crop emergence. Control plots kept weed-infested and weed-free throughout growing season. To assess the weed competition effect on crop characteristics, Richards, Gompertz and logistic equations were fitted to the data. The most abundant weed species were Chenopodium album and Amaranthus retroflexus. Increase in duration of weed interference decreased the stem height of dry bean. At the end of the growing season, dry bean was $20 \mathrm{~cm}$ taller in season-long weed-free treatment compared to the season-long weed-infested treatment. As the number of days of weed interference increased, a declining trend of LAI and number of pods was observed. The minimum number of pods was obtained in season-long weed-infested treatment (5.01 pods/ plant). Weed interference during the whole growing season, caused a $60 \%$ reduction in yield. Considering $5 \%$ and $10 \%$ acceptable yield lost, the critical period of weed competition was determined from 20 to 68 and 23 to 55 days after planting (DAE), respectively.
\end{abstract}

Keywords: acceptable yield lost, biomass, critical period, leaf area index, relative yield

\section{Introduction}

Interplant competition for capture of the essential resources for plant growth (i.e. light, water and nutrients) is one of the key processes determining the performance of agricultural ecosystems (Kropff and Van Laar, 1993). Competition has been defined as 'the tendency of neighboring plants to utilize the same quantum of light, ions of mineral nutrient, molecules of water or volume of space' (Grim, 1979). In agro-ecosystems competition of weeds against crop plant may significantly reduce yield and impair crop quality, resulting in financial loss to the farmer (Kavaliauskaite and Bobinas, 2006). Therefore weed management is one of the important issues in crop production. Manual weed removal is often time consuming and expensive. On the other hand application of herbicide for weed control has an adverse effect to the environment (Ngouajio et al., 1997). The use of integrated weed management systems (IWMS) is advisable to develop optimum weed control strategies and efficient use of herbicides. The Critical Period of Weed Competition (CPWC) is a key consideration for IWMS programs and for the development of alternative weed management (Stagnari and Pisante, 2011). CPWC is a period of crop cycle which weeds intensively compete for obtaining resources and weeds must be controlled to prevent significant yield losses (Hall et al., 1992). The critical period varies based on some factors e.g. weed density (Sattin et al., 1992), crop species and variety (Van Acker et al., 1993), soil temperature and moisture (Retta et al.,
1991). Considering the importance of weed competition in crop production, CPWC has been determined for several crops such as potato, pepper and corn (Ahmadvand et al., 2009; Amador-Ramirez, 2002; Evans et al., 2003).

Dry bean (Phaseolus vulgaris L.) is an economically important crop in western Iran. This plant is highly sensitive to weed interference, mainly during the initial stages of its vegetative development (Carvahlo and Christoffoleti, 2008). Weed competition has adverse effects on bean growth and can severely reduce its yield (Dawson, 1964). Therefore good understanding of the response of dry beans to weed competition as well as the determination of its CPWC is important subjects to consider in its production. Stagnari and Pisante (2011) informed that in French bean weed infestation caused a reduction in Leaf Area Index (LAI) and number of pods. Wilson et al. (1990) cited that there is a negative relationship between weed's dry matter and bean yield. Qasem et al. (1995) reported that weed interference significantly reduced the yield of bean and that the critical period of weed competition was from 14 to 21 days after emergence. In Cameroon CPWC was found between first trifoliate leaf and pod filling stages of bean growth (Ngouajio et al., 1997). Consequently, weed interference has a strong effect on crop growth and yield, hence effective weed management depends on our knowledge of crop-weed interaction. Therefore, the objective of current study was to evaluate effects of weed competition on yield and growth of dry bean. 


\section{Materials and methods}

A field experiment was conducted at the Agricultural Research Station of Hamedan $\left(34^{\circ} 52^{\prime} \mathrm{N}\right.$ latitude, $48^{\circ} 32^{\prime}$ W longitude and $1741.5 \mathrm{~m}$ a.s.l.), in west Iran during 2011 cropping season. The soil type was loamy containing 35\% sand, $40.6 \%$ silt and $24.4 \%$ clay, with a $\mathrm{pH}$ of 8.08 . According to local practice, land was ploughed using a mould board plough and it was disked twice. Fertilizer applications were based on soil test recommendations at the rates of $100 \mathrm{~kg} / \mathrm{ha}$ urea and $100 \mathrm{~kg} / \mathrm{ha}$ super phosphate triple. Seeds were sown manually at the depth of $5 \mathrm{~cm}$. The crop was irrigated after sowing and repeated approximately each week according to weather conditions.

The experiment was a Randomized Complete Block Design with 3 replications, including two series of treatments. The first series, comprised treatments in which weeds were removed at 10,20,30, 40 and 50 days after emergence (DAE) as $\mathrm{WF}_{10}, \mathrm{WF}_{20}, \mathrm{WF}_{30}, \mathrm{WF}_{40}$ and $\mathrm{WF}_{50}$ respectively. Afterwards, the weeds were allowed to compete with the crop until harvest in each case. In the second series, weed interference treatments were applied whereby weeds were allowed to grow with the crop up to 10, 20, 30, 40 and $50 \mathrm{DAE}$ as WI ${ }_{10}, \mathrm{WI}_{20} \mathrm{WI}_{30} \mathrm{WI}_{40}$ and $\mathrm{WI}_{50}$ respectively, after which the plots were kept weed-free until harvest in each case. Control plots kept weed-infested $\left(\mathrm{WI}_{\mathrm{T}}\right)$ and weed-free $\left(\mathrm{WF}_{\mathrm{T}}\right)$ throughout the crop cycle. Weed removal was carried out by hand pulling and hoeing. Weed sampling was done at the time of weed removal for weed-infested treatments and at the time of crop harvest for weed-free treatments. Weeds were harvested in two areas per plot using a $1.0 \mathrm{~m} \times 1.0 \mathrm{~m}$ quadrate and number of each species was recorded. In order to evaluate dry weight, weeds were cut at soil level and dried at $75^{\circ} \mathrm{C}$ to a constant weight. Crop sampling was started 14 days after emergence and repeated 6 times with a 14 days interval. In each sampling, 5 plants were harvested and crop height was determined by measuring the main stem. Also, leaf area index was measured 70 days after crop emergence. Harvesting was done in each plot from the two middle rows of $2 \mathrm{~m}$ long by hand, number of pods and grain yield were then determined. Importance value of weed (IVW) was calculated as follows (Mamun et al., 2011):

IVW $=\frac{\text { Dry weight of a given oven dried weed species }}{\text { Dry weight of all oven dried weed species }} \times 100$

Exponential curve was fitted to the data using following equation, to describe the relationship between weed dry weight and weed-free treatments (Sit and Costello, 1994):

$Y=a \times \exp (b \times x)$

Where, $Y$ is the weed dry weight $\left(\mathrm{g} / \mathrm{m}^{2}\right), a$ and $b$ are coefficients and $x$ is days after emergence. Schumacher's (1939) model was fitted to the weed-infested treatments and weed biomass accumulation:

$Y=\exp (a+b / x)$
Where, $Y$ is the weed dry weight $\left(\mathrm{g} / \mathrm{m}^{2}\right), a$ and $b$ are constants of curve and $x$ is the duration of weed infested period (day). To quantify plant height over time as influenced by weed interference, data were regressed on time (day after emergence) using Richards function (Hunt, 1982):

$$
Y=\frac{Y_{\max }}{[1+\exp (a-b \times T)]^{1 / c}}
$$

Where, $Y_{\max }$ represents maximum height, $a, b$, and $c$ are shape coefficients, and $T$ is days after emergence of crop. The Gompertz equation (Ratkowsky, 1990) was used to describe the effect of increasing duration of weed-free period on bean yield:

$$
Y=A \times \exp [-B \times \exp (-K \times T)]
$$

Where $Y$ is the yield as a percentage of the weed-free control, $A$ is the upper asymptote, $B$ and $K$ are parameters that determine the shape of the curve, and $T$ is the length of the weed-free period after crop emergence on the basis of day.

The logistic model was fitted to the data for increasing duration of weed interference on dry bean yield (Ratkowsky, 1990):

$$
Y=C+\frac{D}{1+\exp (-A+B \times T)}
$$

Where $Y$ is the yield as a percentage of the weed-free control, $A$ and $B$ are parameters that determine the shape of the curve, $C$ is the lower asymptote, $D$ is the difference between the upper and lower asymptotes and $T$ is the duration of weed interference on the basis of days after crop emergence. To evaluate the effect of treatments on weed biomass, height, LAI, number of pods and yield of dry bean, equations were fitted to the data for each treatment, using PROC NLIN (SAS Institute, 1999).

\section{Results and discussion}

Ten weed species infested the experimental plots, which belonged to 8 families (Tab. 1). Three weeds: Chenopodium album, Amaranthus retroflexus and Amaranthus blitoides recorded high Weed Importance Value (30.66, 30.11 and $17.01 \%$ respectively) with C. album being the most dominant (Tab. 1). Total weed biomass increased as the duration of weed-infested period increased (Fig. 1A; Tab. 2). On the other hand, Increase in weed-free periods resulted in a decreasing order of weed total dry weight over time (Fig. 1B; Tab. 2).

Regardless of the weed-infested and weed-free treatments imposed, dry bean stem height was reduced by increase in weed interference periods (Fig. 2A). Compared to other treatments, the season long weed-infested treatments had the lowest increasing trend of crop stem height while the weed-free control increased the dry bean stem height (Fig. 2B). At the end of the growing season, dry bean was $20 \mathrm{~cm}$ taller in season-long weed-free plots than 
72
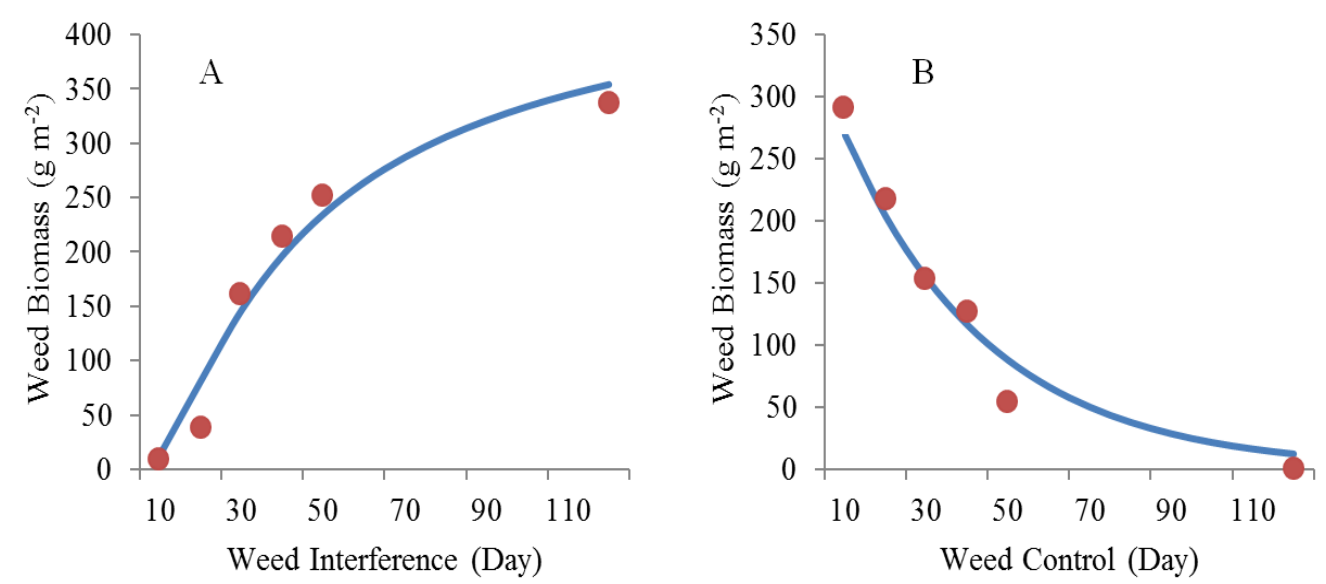

Fig. 1. Effects of increase in duration of weed interference (A) and weed free periods (B) on weed biomass. Dots indicate observed data. Parameter values for fitted curves are given in Tab. 2
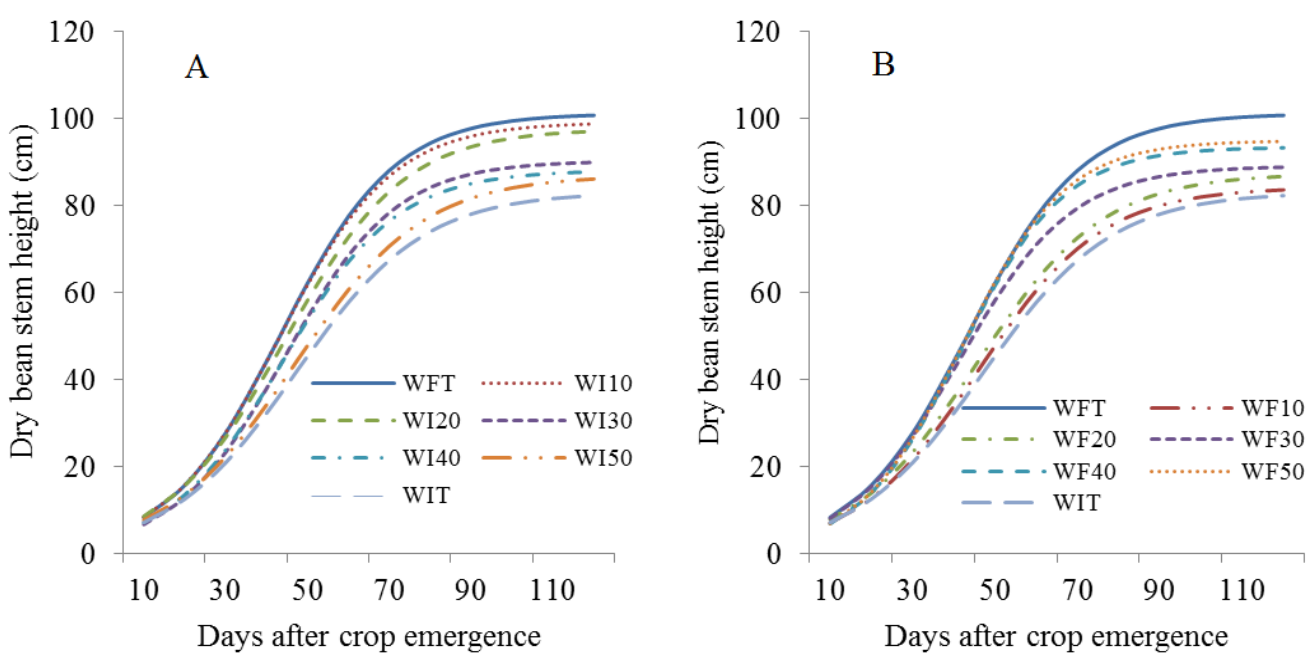

Fig. 2. Effects of increase in duration of weed interference $(A)$ and weed free periods (B) on dry bean height

weed-infested plots. In literature, there are contradictory reports on the effect of weed competition on crop height. Kavurmaci et al. (2010) reported that increase in duration of weed competition significantly reduced faba bean height while Klingman and Oliver (1994) gave similar report on soybean. In contrast, Williams and Lindquist (2007) stated that weed interference increased height of sweet corn. It is suggested that increase in plant height under weed competition is the result of increase in far-red radiation compared to red radiation in consequence of shading (Rohrig and Stutzel, 2001). Smith (1986) concluded that the effects of weed interference on stem elongation were due to increased cell elongation, as no changes occurred in the rates of cell division or node formation.

Tab. 1. Importance value of weed (\%) for different species in season-long weed-infested treatment at the crop harvest

\begin{tabular}{cccc}
\hline Common name & Scientific name & Family & Importance value (\%) \\
\hline Lamb's Quarters & Chenopodium album & Chenopodiaceae & 36.66 \\
Red-root Amaranth & Amaranthus retroflexus & Amaranthaceae & 30.11 \\
\hline Prostrate Amaranth & Amaranthus blitoides & Amaranthaceae & 17.01 \\
\hline Field Bindweed & Convolvulus arvensis & Convolvulaceae & 6.75 \\
Cockspur & Echinocloa crus-galli & Poaceae & 5.51 \\
\hline Corn Sow Thistle & Sonchus arvensis & Asteraceae & 1.65 \\
\hline Green Foxtail & Setaria viridis & Poaceae & 1.42 \\
\hline Common Mallow & Malva neglecta & Malvaceae & 0.38 \\
Greater Plantain & Plantago major & Plantaginaceae & 0.26 \\
\hline Bermuda Grass & Cynodon dactylon & Poaceae & 0.2 \\
\hline
\end{tabular}


Tab. 2. Parameters of the Schumacher (a) and exponential (b) models used to calculate the effect of competition of weeds against dry bean on weed dry weight accumulation

\begin{tabular}{ccccc}
\hline & Equation Model & A & B & $\mathrm{R}^{2}$ \\
\hline (a) & $Y=\exp (a+b / x)$ & 6.16 & -35.2 & 0.89 \\
(b) & $Y=a \times \exp (b \times x)$ & 356.3 & -0.02 & 0.85 \\
\hline
\end{tabular}

In the present experiment, a decrease in crop height, due to weed competition, may be as a result of decrease in essential resources, which consequently might have caused a reduction in cell division, growth and development of the crop (Kropff and Van Laar, 1993).

Weed infestation strongly affects crop leaf area index. Highest LAI was obtained in the season-long weed-free treatment while the contrary was observed in the seasonlong weed-infested plots (Fig. 3A; Tab. 3 and 4). Increase in weed competition resulted in decreased LAI of dry bean. In contrast, LAI increased in weed-free plots due to reduction in competition (Fig. 3A; Tab. 3 and 4). This confirms the findings of Hall et al. (1992) who reported that weed competition severely reduced LAI in corn. Dzomeku et al. (2007) and Evans et al. (2003) observed similar leaf area reductions due to weed interference.

Weed competition had a strong impact on number of pods. A decreasing trend in pods was observed when weedinfestation became more severe over time. The effect of weed-free treatments was contrary as there was an increase in the number of pods in those treatments. Highest number of pods was obtained in season-long weed-free plots

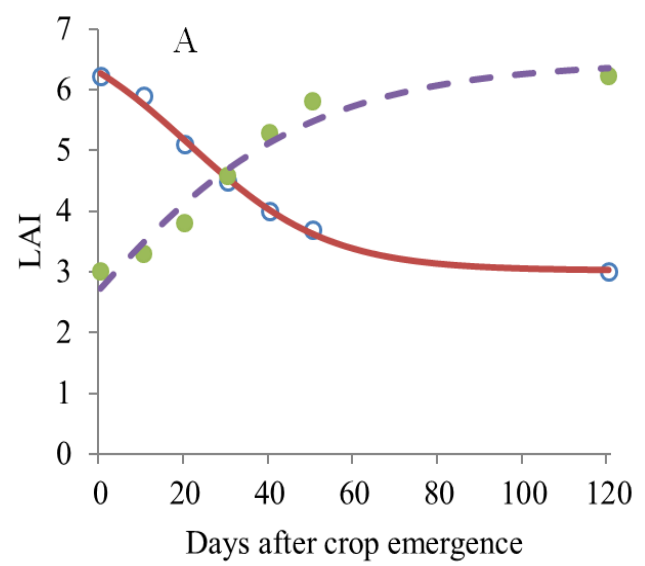

(13.66 pods/plant) compared to season-long weed-infested plots (5.01 pods/plant; Fig. 3B; Tab. 3 and 4). Philip and Bradly (1990) stated that bean pods were severely reduced by weed interference. Van Acker (1992) observed similar results in soybean. In dry bean, pod number has been shown to be the most sensitive yield component to weed competition (Woolley et al., 1993).

Grain yield showed a declining trend with increase in the time of weed infestation (Fig. 4; Tab. 3 and 4). Similar results have been reported by Ngouajio et al. (1997) and Elkoca et al. (2005). This might probably be as a result of shade provided by weed the canopy on the dry bean which might have reduced sun radiation for photosynthesis. Furthermore, dry bean being a C3 plant is more sensitive to water deficit especially when competing with weeds which are C4 plants (Bukun, 2004). All of this can affect development of leaves and cause a reduction in dry bean LAI which in turn might have reduced its capacity to photosynthesize and consequently decreased its ability to produce biomass thereby leading to decrease in yield components.

Considering a 5\% Acceptable Yield Lost (AYL), the CPWC was between 20 and 68 DAE (equal to V2 to R1 of dry bean stages of growth), corresponding to a 48 days long critical period of weed control (Fig. 4A; Tab. 3 and 4). For a $10 \%$ AYL, the CPWC was 32 days long, between 23 and 55 DAE (equal to V2 to V6 of dry bean stages of growth; Fig. 4B; Tab. 3 and 4). Woolley et al. (1993) reported that in white bean, CPWC was from 20 to 40 days after planting. Burnside et al. (1998) stated that from 4 to 6 weeks after crop emergence was the critical period

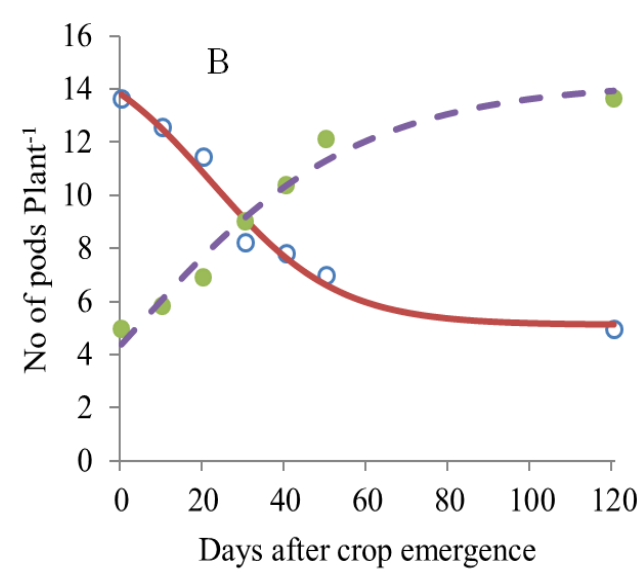

Fig. 3. Effect of increase in duration of weed interference (empty circles) and weed free periods (dots) on dry bean LAI (A) and pods number (B) using logistic and Gompertz equations. Parameter values for fitted curves are given in Tab. 3 and 4

Tab. 3. Parameters estimates of the logistic model used to calculate the effect of weed-infested treatments on crop traits

\begin{tabular}{cccccc}
\hline Crop traits & A & B & C & D & R2 \\
\hline Leaf Area Index & 1.2649 & 0.0606 & 3.0213 & 4.1661 & 0.82 \\
Pods Number & 1.4282 & 0.065 & 5.1214 & 10.7545 & 0.81 \\
Relative Yield & 9.2971 & 0.3394 & 45.5863 & 53.8067 & 0.6 \\
\hline
\end{tabular}

Tab. 4. Parameters estimates of the Gompertz model used to calculate the effect of weed-free treatments on crop traits

\begin{tabular}{ccccc}
\hline Crop traits & A & B & K & $\mathrm{R}^{2}$ \\
\hline Leaf Area Index & 6.4615 & 0.8633 & 0.033 & 0.87 \\
Pods Number & 14.2719 & 1.1788 & 0.0325 & 0.89 \\
Relative Yield & 104.3 & 1.034 & 0.0357 & 0.86 \\
\hline
\end{tabular}


74

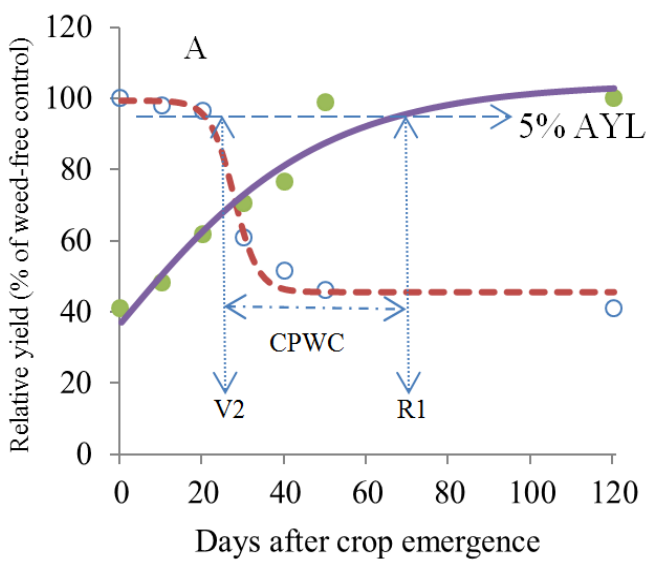

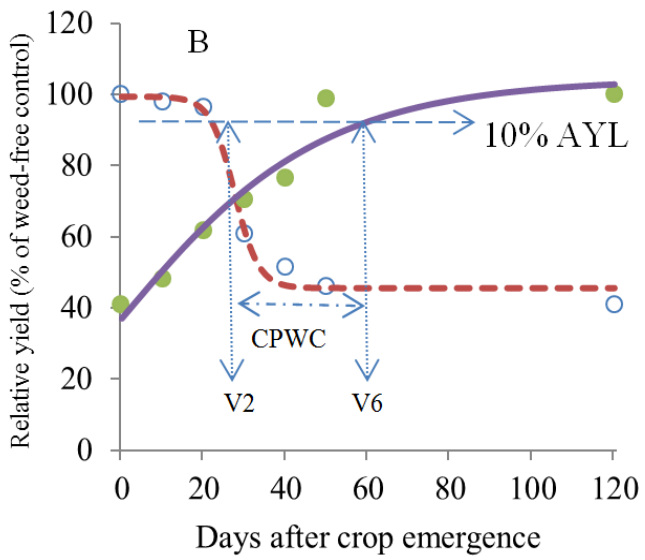

Days after crop emergence

Fig. 4. Effect of increase in duration of weed interference (empty circles) and weed free periods (dots) on relative yield of dry bean. Horizontal dashed arrow indicates acceptable yield lost at 5\% (A) and 10\% (B). Parameter values for fitted curves are given in Tab. 3 and 4

of weed competition of dry bean. At the beginning of CPWC, weeds have been developed enough canopies to compete for essential resources. This time corresponded approximately with the beginning of a significant increase in total weed biomass (Stagnari and Pisante, 2011). Therefore weeds control must start at this point to prevent significant yield losses. At the end of CPWC, developed canopy of dry bean can easily suppress any emerged weed afterwards and no weed removal is necessary any longer.

\section{Conclusions}

Among the weeds identified, $C$. album followed by $A$. retroflexus being dominant weeds in this study have played a striking role in yield loss in dry bean. Weed competition caused a considerable reduction in crop stem height and leaf area index. These occurrences notably will decrease dry bean's light absorption ability. A descending trend was observed between pods number and weed interference duration. At the 5\% and 10\% YLA, the critical period of weed competition was from 20 to 68 and 23 to 55 DAE, respectively. Therefore, weeding within these periods will help to prevent excessive use of herbicides, reduce labor cost and increase grain yield of dry bean.

\section{References}

Ahmadvand G, Farzad M, Golzardi F (2009). Effect of crop plant density on critical period of weed competition in potato. Sci Hortic 121:249-254.

Amador-Ramirez MD (2002). Critical period of weed control in transplanted chilli pepper. Weed Res 42:203-209.

Bukun B (2004). Critical periods for weed control in cotton in Turkey. Weed Res 44:404-412.

Burnside OC, Weinse MJ, Holder BJ, Weisberg S, Ristau EA, Johnson MM, Cameron JH (1998). Critical period for weed control in dry bean (Phaseolus vulgaris). Weed Sci 46:301306.
Carvalho SJP, Christoffoleti PJ (2008). Competition of Amaranthus Species with dry bean plants. Sci Agric 65:239-245.

Dawson JH (1964). Competition between irrigated field beans and annual weeds. Weeds 12:206-208.

Dzomeku IK, Wilson D, Ebenezer T (2007). Responses of NERICA rice varieties to weed interference in the Guinea Savannah uplands. J Agro 6:262-269.

Elkoca E, Kantar F, Zengin H (2005). Weed control in lentil (Lens culinaris) in eastern Turkey. New Zealand J Crop Hort Sci 33:223-231.

Evans SP, Knezevic SZ, Lindquist JL, Shapiro CA, Blankenship EE (2003). Nitrogen application influences the critical period for weed control in corn. Weed Sci 51:408-417.

Grim JP (1979). Plant strategies and vegetation processes. Willey Chichester, $222 \mathrm{p}$.

Hall MR, Swanton CJ, Glenn WA (1992). The critical period of weed control in grain corn (Zea mays). Weed Sci 40:441447.

Hunt R (1982). Plant growth curves: The functional approach to growth analysis. Arnold E Publ Ltd, London, 128 p.

Kavaliauskaite D, Bobinas A (2006). Determination of weed competition critical period in red beet. Agron Res 4:217220.

Kavurmaci Z, Karadavut U, Kokten K, Bakoglu A (2010). Determining critical period of weed-crop competition in faba bean (Vicia faba). Int J Agric Biol 12:318-320.

Klingman TE, Oliver LR (1994). Influence of cotton (Gossypium hirsutum) and soybean (Glycine max) planting date on weed interference. Weed Sci 42:61-65.

Kropff MJ, Van Laar HH (1993). Modelling crop-weed interactions. CAB International, Wallingford, $274 \mathrm{p}$.

Mamun MAA, Shultana R, Siddique MA, Zahan MS, Pramanik S (2011). Efficacy of different commercial product oxadiazon and pyrazosulfuron-ethyl on rice and associated weeds in dry season rice cultivation. World J Agri Sci 7:341-346.

Ngouajio M, Foko J, Fouejio D (1997). The critical period of 
weed control in common bean (Phaseolus vulgaris L.) in Cameroon. Crop Prot 16:127-133.

Philip EN, Bradly AM (1990). Common cocklebure (Xanthium stramarium) interference in snap bean (Phaseolus vulgaris L.). Weed Technol 4:743-748.

Qasem JR (1995). Critical period of weed interference in irrigated snap bean. Adv in Hort Sci 9:23-26.

Ratkowsky DA (1990). Handbook of Nonlinear Regression Models. Marcel Dekker, New York, USA.

Retta A, Vanaderlip RL, Higgins RA, Moshier LJ, Feyerherm AM (1991). Suitability of corn growth models for incorporation of weed and insect stresses. Agron J 83:757-765.

Rohrig M, Stutzel H (2001). Canopy development of Chenopodium album in pure and mixed stands. Weed Res 41:111228.

SAS Institute (1999). The SAS system for Windows. Version 9.1 SAS Inst., Cary, NC.

Sattin M, Zanin G, Berti A (1992). Case history for weed competition population ecology: Velvetleaf (Abuitilon theophrasti) in corn (Zea mays). Weed Technol 6:213-219.

Schumacher FX (1939). A new growth curve and its application to timber-yield studies. J For 37:819-820.

Sit V, Costello MP (1994). Catalog of Curves for Curve Fitting. Biometrics Information Hand book Series. Ministry of Forests BC. Victoria Canada.
Smith H (1986). The perception of light quality, 187-217 p. In: Kendrick RE, Kronenberg GHM (Eds.). Photomorphogenesis in Plants. Nijhoff, Dordrecht, The Netherlands.

Stagnari F, Pisante M (2011). The critical period for weed competition in French bean (Phaseoulus vulgaris L.) in Mediterranean areas. Crop Prot 30:179-184.

Van Acker RC (1992). The critical period of weed control in soybean (Glycin max L.) and the influence of weed interference on soybean growth. Weed Sci 11:345-356.

Van Acker RC, Swanton CJ, Weise SF (1993). The critical period of weed control in soybean [Glycine max (L.) Merr]. Weed Sci 41:194-200.

Williams M, Lindquist JL (2007). Influence of planting date and weed interference on sweet corn growth and development. Agron J 99:1066-1072.

Wilson JR, Wicks GA, Fenter CR (1990). Weed control in field bean sustainable agriculture systems. Weed Technol 8:403407.

Woolley BL, Michaels TE, Hall MR, Swanton CJ (1993). The Critical period of weed control in white bean. Weed Sci 41:180-184. 